Mr Miroslav Savanović, potpukovnik, dipl. inž. VP 9808, Beograd

\title{
BESPILOTNE LETELICE
}

\section{Uvod}

Bespilotne letelice (BL) pripadaju grupi najsavremenijih sredstava čija se upotreba najčešće vezuje za zadatke osmatranja, izviđanja, prikupljanja obaveštajnih podataka, elektronska i protivelektronska dejstva i za navođenje na cilj minteligentnih" ubojnih sredstava. Njihova upotreba datira od 1982. godine kada ih je prvo upotrebilo izraelsko RV.

Radi lakše sistematizacije BL prihvaćeno je nekoliko uslovnih podela:

- prema dometu i letnoj izdržljivosti: za bliska rastojanja, za male, srednje i velike domete.

- prema nameni: osmatračke, izviđačke, obaveštajne, za elektronska i protivelektronska dejstva, za udarna dejstva sa samouništenjem i za civilne potrebe;

- prema nivou upotrebe: taktičke (do $300 \mathrm{~km}$ dometa) i operativne (do $900 \mathrm{~km}$ dometa).

Ipak, osnovni i najčešći zahtev koji se postavlja pred BL je prikupljanje relevantnih podataka o protivniku $i$ njihov prenos $u$ realnom vremenu. To se ostvaruje najsavremenijom elektronskom, optoelektronskom, IC, radarskom, laserskom i telekomunikacijskom opremom, uključujući i opremu instaliranu na avionima tipa AWACS, HAWKEYE ili satelitima. U pogledu proizvodnje $\mathrm{i}$ integracije sistema $\mathrm{BL}$, te raznovrsnosti opreme, a time i mogućnosti za izvršenje različitih zadataka, nesporan primat u ovoj oblasti ima Izrael. Pored Izraela koji u razvoju sarađuje sa SAD i evropskim zemljama, značajni proizvođači su SAD i Francuska.

\section{Bespilotne letelice SAD}

Aprila 1996. godine oružane snage SAD obelodanile su svoje tekuće planove $u$ oblasti bespilotnih letelica (UAV - Unmanned Aerial Vehicle) čija namena obuhvata najširi mogući spektar zadataka, uključujući izviđanje na malim rastojanjima, otkrivanje ciljeva, kao i osmatranje u što većoj neprijateljevoj dubini (do $900 \mathrm{~km}$ ). Američki Biro za zajedničke projekte u oblasti bespilotnih letelica (JPO UAV Joint Project Office for UAV), podelio je BL u četiri sloja, označena brojevima: $1,2,2+$ i $3-$, formirajući na taj način "široki kišobran".

Sloj br. 1 čini sistem GNAT-750 firme "General Atomics« koji su pod komandom CIA neprekidno leteli iznad teritorije prethodne Jugoslavije. Ove BL obezbeđuju $24-40$ časovni let na visinama 1585 do 7617 metara (5000 do 25000 stopa) sa korisnim teretom mase $64 \mathrm{~kg}$.

Sloj br. 2 čine letelice sa srednjom izdržljivošću (MAE - Medium Altitu- 
de Endurance). Ovaj sloj pokrivaju letelice tipa PREDATOR, takođe firme "General Atomics«. U sastav sloja br. 2 ulazi 10 letelica i 3 lansirne rampe sa opremom koja radi u svim vremenskim uslovima. Vreme trajanja leta je od 24 do 40 časova, na visinama od 7617 metara i sa korisnim teretom mase $200 \mathrm{~kg}$ u čiji sastav ulaze: elektro-optički i infra-crveni (IC) senzori, osmatrački i izviđački radari i linkovi za prenos podataka.

Sloj br. 2+ činiće letelice velike izdržljivosti (HAE - High Altitude Endurance) za koje zahtevi još nisu potpuno definisani. Očekuje se izbor između dve opcije čije je testiranje prototipskih $\mathrm{BL}$ obavljeno u prvoj polovini 1996. godine. Po izboru odgovarajuće opcije očekuje se narudžba za proizvodnju 8 letelica i 2 zemaljske lansirne stanice za dalje operativno testiranje pre nego što se pristupi serijskoj proizvodnji. Osnovni zahtev za letelice sloja br. $2+$ su "nevidljive« (stealth) karakteristike, veliki domet i veliki korisni teret. Očekuje se da će nabavka obuhvatiti oko 100 sistema u vrednosti oko 230 miliona USD. U procesu ocenjivanja nalaze se predlozi sledećih firmi: "Northrop Grumman", "Loral Western Development«, "Raytheon/ /Lockheed «, »Orbital Sciences« i »Teledyne-Ryan «.

Sloj br. 3- treba da čine letelice značajnih mogućnosti, ali jeftinije od letelica sloja $2+$. $\mathrm{Za}$ sloj br. 3- razvojni tim firme "Lockheed/Boeing" predložio je koncept tipa bumeranga koji ima izdržljivost od 8 časova leta, dolet od oko $900 \mathrm{~km}$ na visini od oko 13500 metara i sa korisnim teretom mase $360 \mathrm{~kg}$, koji u svom sastavu ima radarske i(ili) elektro-optičke senzore.

$\mathrm{Na}$ planu BL za bliska rastojanja američka vojska je pre manje od tri godine odbacila tada aktuelni koncept. Ovo područje je privremeno pokriveno programom BL tipa HUNTER.
Američke agencije, kao što je CIA, ipak su nastavile sa daljim razvojem već aktuelnih sistema. Tako su BL tipa GNAT-750 korišćene u zadacima iznad Bosne u toku 1994. godine iz baza u Albaniji i kasnije u Hrvatskoj. Međutim, letelice GNAT-750 i PREDATOR u pogledu čisto vojnih zadataka zaustavljene su u fazi koja je opisana kao »demonstracija naprednog tehnološkog koncepta«.

$\mathrm{U}$ ispunjavanju visokih zahteva američke vojske u ovom području najznačajnija mesta izborile su sledeće firme: TRW/IAI - Israel Aircraft Industries), „Teledyne-Ryan«, „General Atomics«, ali najprestižniji je razvojni tim firme TRW/IAI.

Bespilotna letelica HUNTER izabrana je na osnovu zahteva američkog Ministarstva odbrane za izviđanja malog dometa, osmatranje i akviziciju podataka o cilju na daljinama 150 do $300 \mathrm{~km}$, tj. na taktičkom nivou. Letelica ima konstrukciju sa modularno koncipiranim korisnim teretom pogodnim za zadatke na liniji fronta, sa visokim koeficijentom cena-efikasnost. Zamišljena je kao višenamenski sistem za izvršavanje osnovnih zadataka u kopnenoj vojsci, zadataka vezanih za brodske raketne sisteme $u$ mornarici i za zadatke instrumentalnog praćenja manevra $u$ izviđačkim zadacima kopnene vojske. HUNTER je podvrgnut izvesnim sistemskim poboljšanjima, kao što su: poboljšanje motora, obezbeđenje modova rada za auto-praćenje i auto-pretraživanje, ugradnja automatskog sistema za prizemljivanje; razvoj zemaljske upravljačke stanice i zemaljskog terminala za prijem podataka u verziji za praćenje manevra.

Konstrukcija ove BL je vrlo jednostavna. Pokreću je dva motora od po $50 \mathrm{~kW}$. Dužina letelice je $6,9 \mathrm{~m}$, a raspon krila $8,9 \mathrm{~m}$. Leti na visini od +500 metara sa brzinom krstarenja od 
$148 \mathrm{~km} / \mathrm{h}$, a maksimalna brzina je 204 $\mathrm{km} / \mathrm{h}$. Zapremina prostora namenjenog za smeštaj korisnog tereta je $2 \mathrm{~m}^{3}$. Letelica ima masu pri poletanju od 726 $\mathrm{kg}$, uključujući $113 \mathrm{~kg}$ korisnog tereta.
HUNTER ima mogućnosti nadgledanja digitalnih komunikacija, relejnog prenosa podataka za avijaciju i izvođenje zadataka iz okvira elektronskih i protivelektronskih dejstava.

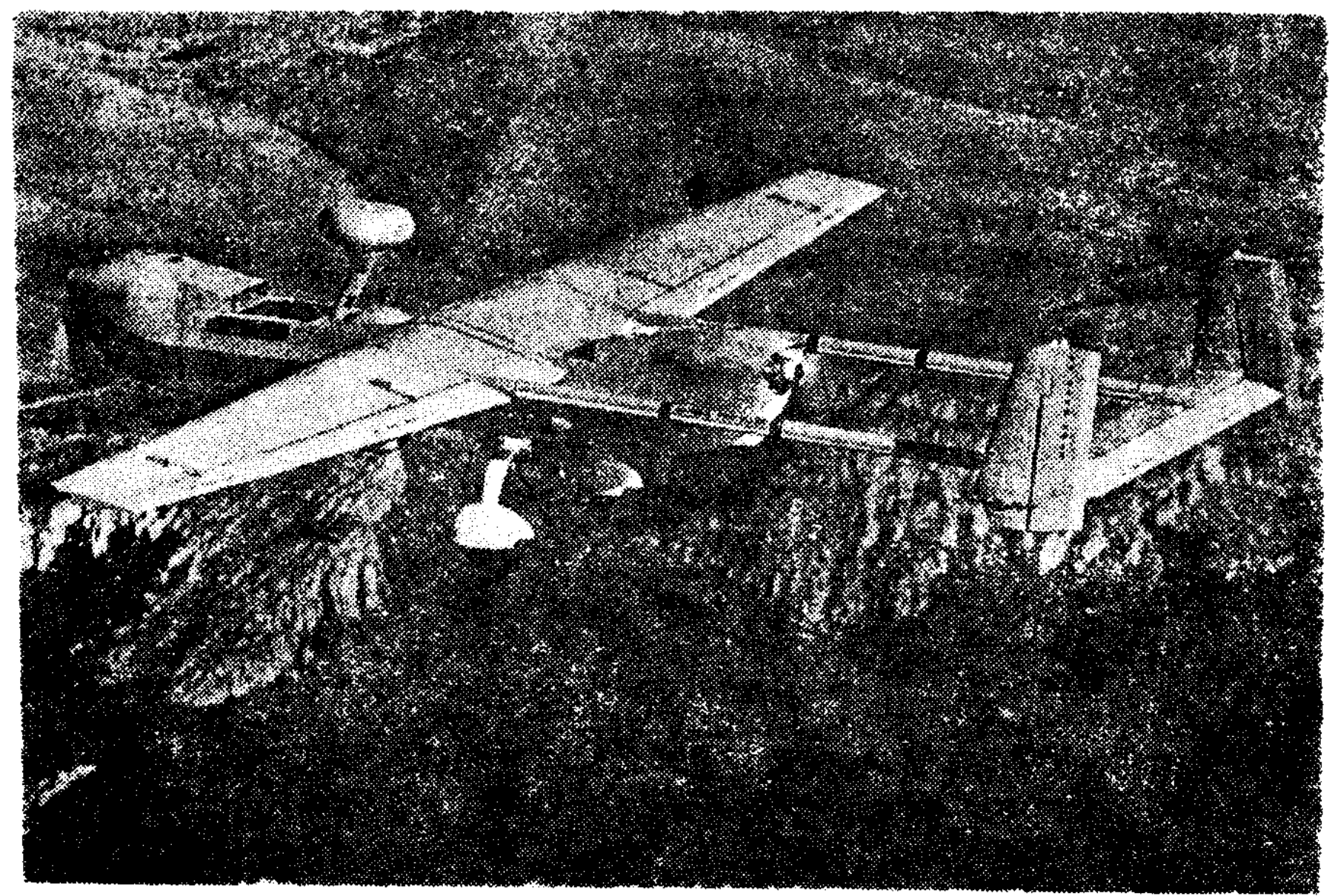

Sl. 1 - Američka BL HUNTER

Može biti lansirana uz pomoć raketnog sistema sa kopnenih ili mornaričkih platformi. Letna izdržljivost je 12 časova. Ova BL može se transportovati transportnim avionima C-130 HERCULES ili bilo kojim drugim američkim velikim transportnim avionima. Višenamenska optronička stabilizovana oprema ima zglobno, tj. kardanski učvršćene senzore za dnevno-noćno praćenje po azimutu od $360^{\circ}$, sa linkom za prenos TV podataka na zemaljske upravljačke uređaje koji su kao stanica za planiranje putanje i upravljanje letom (MPCS - Mission Planning and Control Station) ugrađeni na motorno vozilo koje se u borbenom poretku može nalaziti znatno ispred zemaljske lansirne i upravljačke stanice $\mathrm{i} / \mathrm{ili}$ daljinskog video terminala (RVT - Remote Video Terminal).
Relejni prenos podataka vrši se do izviđačkih mesta na nivou brigada i bataljona koja mogu da dobiju podatke o potencijalnom cilju sa osmatračkih uređaja velikih letelica kao što su: JSTARS, AWACS, HAWKEYE. Ovi podaci mogu zatim biti poslati BL HUNTER (preko zemaljskih upravljačkih stanica) radi verifikacije, praćenja ili nišanjenja.

Prva isporuka ovih BL realizovana je 1995. godine, ali je u prvih 8 meseci upotrebe ovih letelica došlo i do nekoliko udesa nepoznatog uzroka. Uprkos tome narudžbe su produžene. BL HUNTER, kao zajednički proizvod američke firme TRW i izraelske "Malat«, nude se i francuskim oružanim snagama. Navedene firme zajednički produžavaju ulaganje u razvoj u sme- 
ru povećanja izdržljivosti. Tako usavršen sistem nosi oznaku E-HUNTER.

U okvirima američke vojne industrije, najveću ulogu u razvoju $\mathrm{BL}$ još uvek ima firma "General Atomics«. Ona je 1992. godine demonstrirala svoju BL kandidovanu za konkurs američke vojske za zajedničku taktičku BL. Bila je to manevribilna varijanta $B L$ malog dometa pod imenom PROWLER. Dimenzije ove 'BL su: dužina $3,35 \mathrm{~m}$, raspon krila $5,4 \mathrm{~m}$, masa $90,7 \mathrm{~kg}$, maksimalna operativna visina leta $6300 \mathrm{~m}$, brzina leta $278 \mathrm{~km} / \mathrm{h}$ i izdržljivost (vreme zadržavanja u vazduhu) preko 6 časova.

Bespilotna letelica PREDATOR, firme "General Atomics", pripada grupi letelica srednje izdržljivosti, a oblik tela sličan je telu letelice PROWLER, ali većih dimenzija (dužina $8,1 \mathrm{~m}$, raspon krila $14,7 \mathrm{~m}$ sa oborenim repnim dihedralnim krilima). U stanju je da leti 24 časa i održava vezu sa stanicom, leteći na udaljenost od $926 \mathrm{~km}$ od lansirne tačke. Raspolaže sa linkom
Za zadatke na velikim daljinama "General Atomics« je projektovao BL GNAT-750 - avio-transportabilan sistem koji se ne razlikuje mnogo od modela drugih kompanija, ali je nešto veći: dužina 4,95 m, raspon krila 10,12 $\mathrm{m}$, poletna masa $500 \mathrm{~kg}$. GNAT-750 doseže visinu od $7600 \mathrm{~m} \mathrm{u}$ kružnoj putanji sa izdržljivošću većom od 40 časova i dometom većim od $750 \mathrm{~km}$. Ova letelica ima autonomnu navigaciju uz pomoć inercijalnog sistema i sistema za globalno pozicioniranje. U sastav korisnog tereta ulaze: TV senzori, TV senzori niskog nivoa signala, IC senzori, FLIR (napred gledajući IC) senzori koji linijski skeniraju površinu kao i laserski merači daljine, elektronski sistemi, linkovi podataka, radio-releji, radarska oprema i detektori digitalnih komunikacija.

Sve ove BL podržane su zemaljskim upravljačkim sistemima koje, takođe, projektuje "General Atomics", a nalaze se na listama minimalnog izvoza kritičnih tehnologija, što znači da ih proizvođači ne mogu prodavati slo-

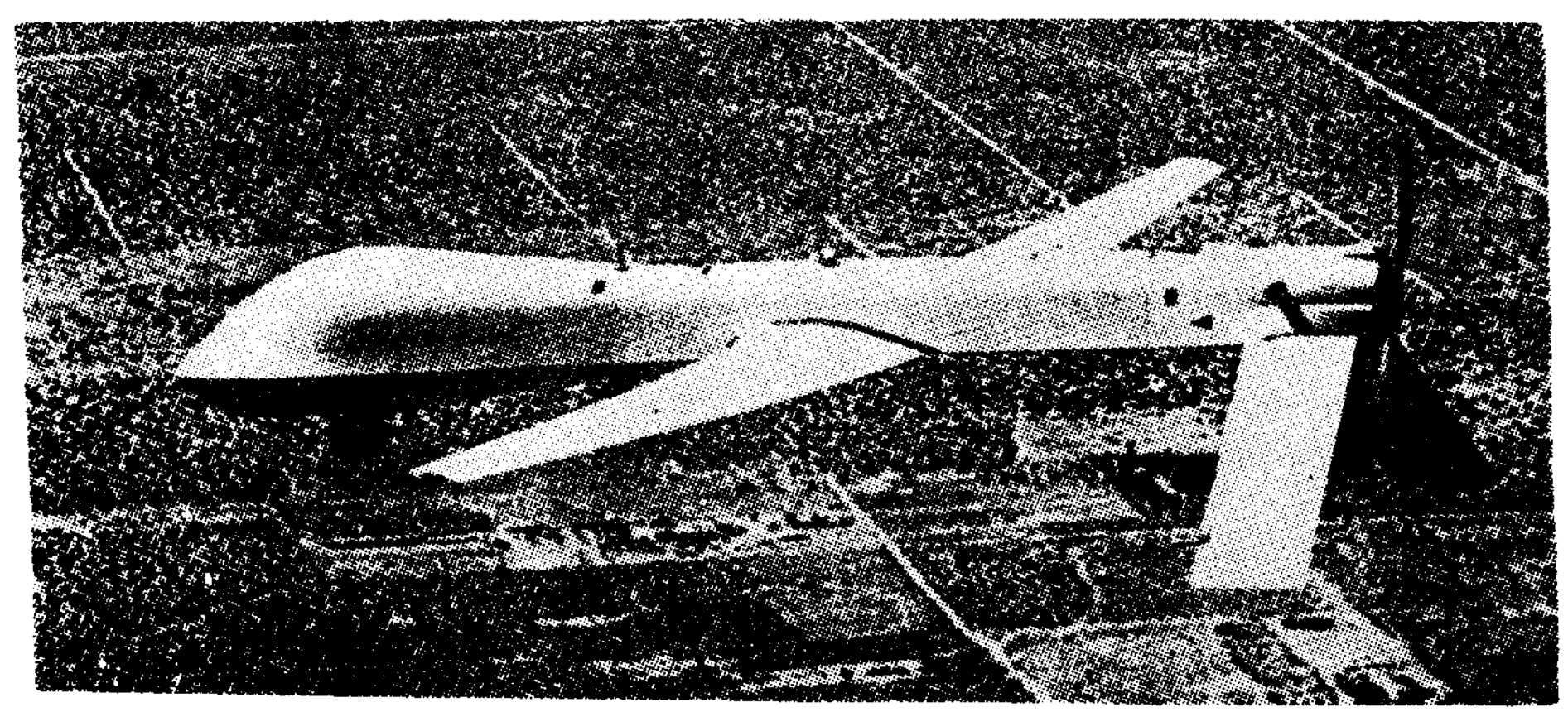

Sl. 2 - Američka BL PREDATOR

podataka promenljive frekvencije $u$ C-bandu i elektro-optičkim i IC senzorima. Navigacija je realizovana uz pomoć inercijalnog navigacijskog sistema čiju kontrolu obavlja sistem za globalno pozicioniranje (GPS). bodno već samo po odobrenju Ministarstva odbrane SAD. Strah od nekontrolisanog izvoza pravda se činjenicom da se ove BL vrlo lako mogu pretvoriti u krstareće rakete, sposobne da zamenom korisnog tereta, sastavljenog 
od elektronske opreme sa bojnom glavom, nanesu precizne udare na izabrane objekte.

\section{Izraelske bespilotne letelice}

Još 1982. godine izraelsko RV uvelo je u svetu tada sasvim novi borbeni koncept - bespilotne letelice postale su osnovno sredstvo na bojnom polju. U toku operacija u Libanu njihova letelica SCOUT je, noseći jednostavnu dnevnu kameru, identifikovala lokaciju sirijskih raketnih baterija raketa SAM-8 u dolini Beka. Letelice su odmah slale fotografije pokretnih baterija, a nekoliko minuta kasnije poletali su parovi aviona, pronalazili ih $\mathrm{i}$ uništavali. Ovakav koncept prikupljanja obaveštajnih podataka ubrzo su analizirale sve savremene armije sveta. Uvidele su se velike mogućnosti ovog koncepta $\mathrm{i}$ ubrzo je bio primenjen $\mathrm{u}$ gotovo svim ratnim sukobima. Izraelska avio-industrija je prva počela sa masovnijom proizvodnjom bespilotnih letelica, i ima iskustvo od 25 godina $u$ njihovom razvoju i proizvodnji, te su gotovo sve zapadne zemlje sarađivale s njom, jer na ovom polju predstavlja nesporan autoritet. Izraelska industrija bespilotnih letelica, ipak, najviše sarađuje sa američkim Biroom za zajedničke projekte $u$ oblasti $B L$, tako da je i usvojila njihove podele prema dometu, izdržljivosti i nameni. Pored osnovnih vrsta izraelska avio-industrija nudi i BL za čisto napadačke zadatke. $\mathrm{U}$ zavisnosti od namene, izraelske BL mogu biti opremljene i opremom drugih proizvođača. Izraelska avio-industrija razvija, proizvodi i vrši integraciju sistema BL, kao i njihovog korisnog tereta, upravljačkog sistema, linkova podataka, lansirne i prateće opreme.

Razvoj izraelskih BL može se pratiti kroz nekoliko generacija $u$ poslednjih 25 godina.
Prvu generaciju projektovanu pre 25. godina predstavljala je mini $B L$ SCOUT, mase $158 \mathrm{~kg}$, koja je za izraelske oružane snage obavljala dnevno-noćne obaveštajne zadatke. Bila je to prva izraelska BL koja je imala mogućnost prenosa podataka $u$ realnom vremenu i sa kojom su stečena iskustva za vreme borbi 1982. godine, u operaciji poznatoj pod nazivom »Mir za Galileju«. Ova BL je godinama bila glavna taktička letelica izraelske vojske.

Drugu generaciju predstavlja BL pod imenom PIONEER, čija je konstrukcija izvedena primenom kompozitnih materijala. Iako ima sličnu namenu kao SCOUT, ipak ima bolje letne performanse: domet $150 \mathrm{~km}$, letnu izdržljivost 6,5 časova, masu $190 \mathrm{~kg}$. Ova letelica je jednostavne konstrukcije sa jednim potisnim propelerskim motorom i dvostrukim lansirno-sletnim uređajem koji omogućava uzletanje i sletanje na betonske ili travnate staze. Ima mogućnost lansiranja i sa mornaričkih platformi. PIONEER je prilagođen i zahtevima američke vojske (RM i raketne jedinice) koja ga je koristila u operaciji "Pustinjska oluja" uglavnom za osmatračke zadatke. Prema američkim izveštajima 26 od 40 ovih BL uništila je iračka PA vatra iz oružja malih kalibara, ili zbog udesa, ali su korišćene i za uništavanje kritičnih ciljeva u kamikaza stilu. PIONEER je u vezi s američkim zahtevima bio jedna faza u zajedničkom razvoju nove taktičke $B L$ pod imenom HUNTER koja će ući.u upotrebu krajem ove dekade.

BL RANGER je sistem koji je specijalno dizajniran za uslove evropskog ratišta $\mathrm{i}$ kasnije je proizveden $u$ kooperaciji sa švajcarskom firmom »Oerlikon-Contraves« za švajcarske oružane snage. RANGER ima masu od 275 $\mathrm{kg}$, višenamensku opremu kao i auto- 
matski poletno-sletni uređaj sa laserskim senzorima. Ponuđen je i oružanim snagama Holandije.

Treću generaciju BL predstavlja SEARCHER koji je predviđen da u izraelskim oružanim snagama zameni $\mathrm{BL}$ SCOUT. Prema dostupnim izvorima, ova $B L$ je isporučena i singapurskim oružanim snagama.

SEARCHER ima masu od $317 \mathrm{~kg}$, poboljšanu aerodinamičku konstrukciju izvedenu od kompozitnih materijala, kao i novi rep i repno kormilo. Jednopropelerski potisni motor obezbeđuje četrnaesto-časovnu letnu izdržljivost, a dubina prodora $\mathbf{u}$ neprijateljevu teritoriju može da se poveća upotrebom prenosne upravljačke stanice poleće i sleće pomoću točkova na betonsku ili travnatu stazu. Alternativno može se lansirati i uz pomoć raketnog ili pneumatskog sistema i zaustaviti uz pomoć kočeće zaustavne sajle ili mreže.

$\mathrm{Na}$ planu povećanja izdržljivosti firma "Malat" razvila je sasvim novu BL pod imenom HERON. To je BL za srednje visine $(10000 \mathrm{~m}$ i više) sa izdržljivošću od preko 50 časova. Cetvorocilindrični motor sa turbo punjačem, snage $73,5 \mathrm{~kW}$, daje letelici brzinu od $222 \mathrm{~km} / \mathrm{h}$. Maksimalna masa pri poletanju je $1150 \mathrm{~kg}$. Svoj prvi let HERON je izveo krajem 1994. godine. Sistem je projektovan tako da može prihvatiti različitu opremu koja omogu-

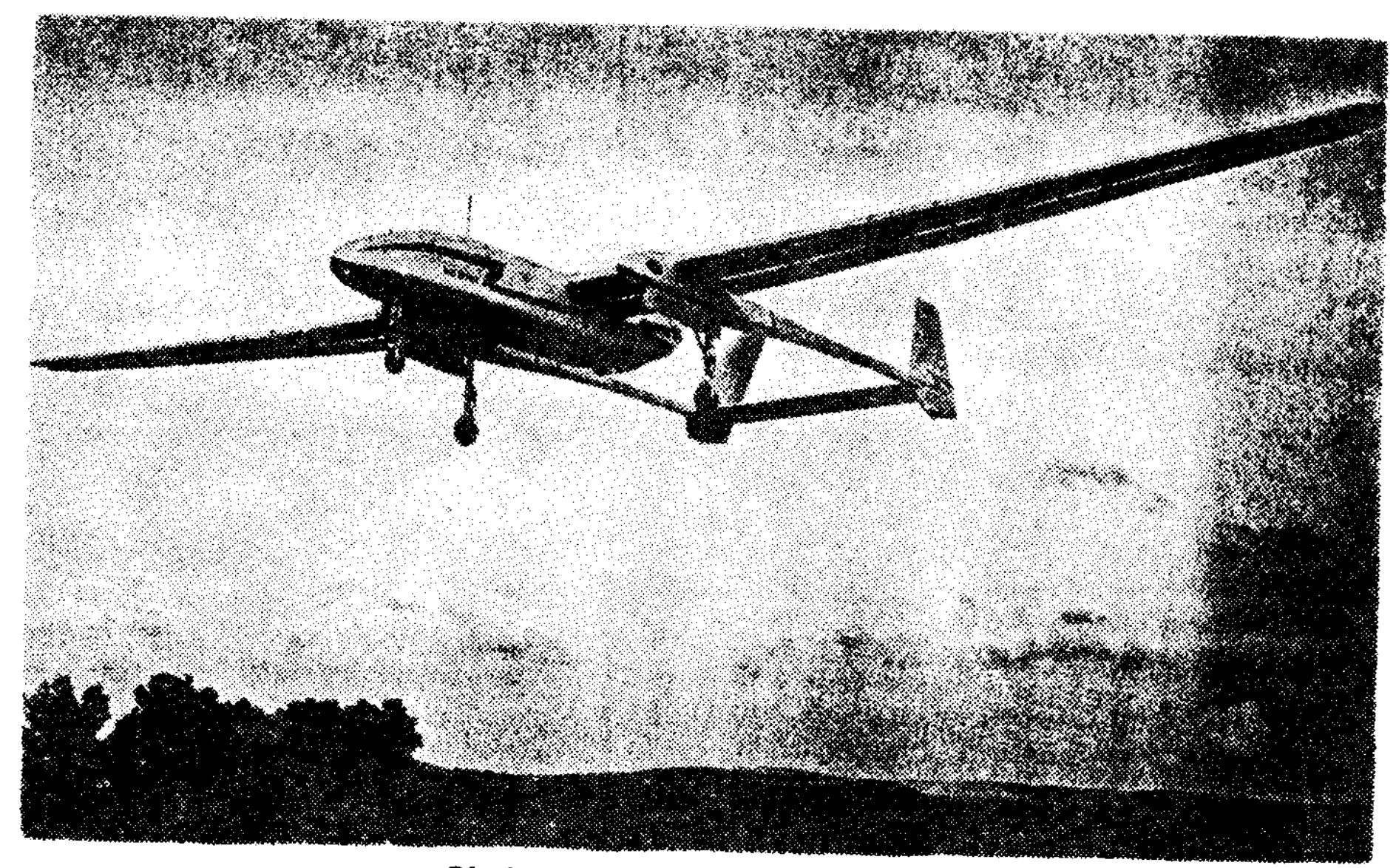

Sl. 3 - Izraelska BL HERON

koja može da deluje iz rejona taktičkih jedinica na samoj liniji fronta. Nova upravljačka stanica sistema SEARCHER može da bude snabdevena bazom podataka koji opisuju reljef terena iznad kojeg BL leti, kao i drugim detaljima koje zahteva konkretni zadatak. Letelica može da ponese različite terete mase do $63,6 \mathrm{~kg}$, a može da ćava osmatranje u realnom vremenu, vođenje elektronske i protivelektronske borbe, obavljanje uloge releja u telekomunikacijama, kao i pomorsko patroliranje.

Poslednji sistem BL firme "Malat " nosi ime EYE-VIEW. Projektovan je za upotrebu na bliskim rastojanji- 
ma na taktičkom nivou. Ova vrlo laka $\mathrm{BL}$, mase $90-100 \mathrm{~kg}$, nosi opremu mase $15-30 \mathrm{~kg}$ i ima domet od preko $100 \mathrm{~km}$. Minijaturiziranom upravljačkom stanicom na bazi personalnog računara rukuje posada od tri člana. Stanica se nalazi na pukovskom ili bataljonskom nivou. Standardni komplet sistema čine tri letelice i upravljačka stanica. Platnena paraglajderska konstrukcija omogućava ovoj letelici da lebdi iznad cilja i da sleće na vrlo kratke staze.

Zemaljska upravljačka stanica predstavlja srce sistema i održava vezu sa letelicom, upravlja njenim letom, kao i radom i karakteristikama opreme korisnog tereta i u potpunosti nadgleda izvršenje zadatka.

Firma "Malat« razvila je nekoliko vrsta takvih stanica koje su prilagodljive za različite $\mathrm{BL}$.

Zemaljska upravljačka stanica GCS-2000 je stanica druge generacije zasnovana na mikroprocesoru. Koristi usavršeni link za prenos podataka. Stanica treće generacije GCS-3000 razvijena je po američkim zahtevima za program BL kratkog dometa. "Malat" je, takođe, razvio prenosnu upravljačku stanicu za upotrebu na taktičkom nivou, zapravo minijaturizovanu upravljačku jedinicu (MCU - Mission Control Unit) na bazi GCS-2000 koja omogućava upravljanje bespilotnim letelicama sa isturenih položaja.

$\mathrm{Na}$ polju softvera firma "Malat" radi na konverziji programa za $B L$ rađenih $u$ različitim programskim jezicima u programski jezik ADA (standardni jezik američke vojske) u okviru razvoja programa za automatsko pretraživanje terena i prizemljivanje.

BL mogu da se koriste i za istraživanja $u$ civilnim programima, kao što su: kontrola i upravljanje prirodnom okolinom ili u slučaju prirodnih katastrofa, policijska služba, pravosuđe, geološki ili topografski nadzor. Opisani sistemi, kao što su PIONEER, SEARCHER i HUNTER, mogu se prilagoditi navedenim namenama.

Istraživanja koja se sprovode u poslednje vreme obuhvataju i razvoj antiradarske napadačke BL koja predstavlja distancioni (stand-off) oružni sis-

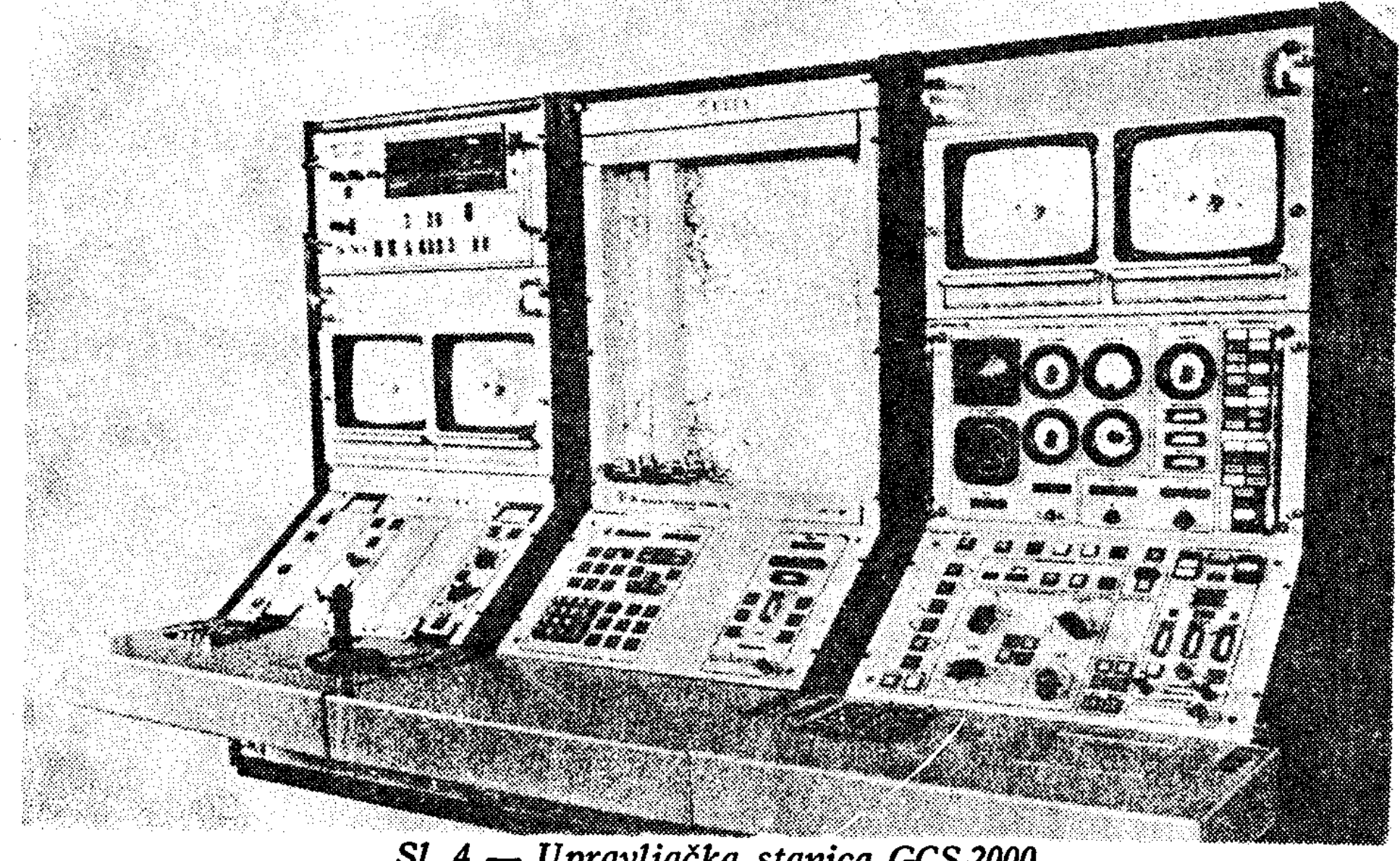

Sl. 4 - Upravljačka stanica GCS-2000 
tem pod imenom HARPI koji je projektovala izraelska industrija. Prema dostupnim izvorima kupci ovog sistema su izraelske $\mathrm{i}$ indijske oružane snage. HARPI je BL velikog dometa (verovatno preko $100 \mathrm{~km}$ ), koja prodire duboko $u$ neprijateljevu pozadinu. Predviđena je za lansiranje sa višestrukog lansirnog kontejnera montiranog na običnom teretnom motornom vozilu. Ona može da nosi izviđačke senzore i senzore za detekciju ili bojne glave za uništenje neprijateljevog radara. U slučaju kada nosi bojnu gla$\mathrm{vu}$, nakon lansiranja BL ne može da se vrati na mesto lansiranja.

Pored firme "Malat « značajan proizvođač BL u Izraelu je i firma »Silver Arrow«. Ona je 1993. godine proizvela prototip BL pod imenom MICRO VEE, čiji su letni testovi nastavljeni 1994. godine. Ova BL ima mogućnost prenosa video informacija $u$ realnom vremenu (opciono se ugrađuje i laka FLIR oprema) mogućnost autonomnog leta sa ručnim korekcijama i redundansnu konfiguraciju pogonskog motora. Dimenzije ove BL su: raspon krila $3,6 \mathrm{~m}$, masa pri poletanju $45 \mathrm{~kg}$, uključujući i maksimalno $8 \mathrm{~kg}$ korisnog tereta. Akcioni radijus letelice je $50 \mathrm{~km}$, a izdržljivost 5 časova. Komplet sistema čini 5 letelica, lanser, upravljačka jedinica, zemaljski terminal podataka i zemaljska pomoćna oprema. Sva oprema transportuje se jednim vozilom, a posadu čine dva člana.

U februaru 1994. godine firma »Silver Arrow « predstavila je i BL pod imenom HERMES-450 sa dvojnim motorom i konstrukcijom od kompozitnog materijala. Ova BL projektovana je da ponese korisni teret mase $150 \mathrm{~kg}$ i obezbedi izdržljivost od 24 časa pri létu na visini od $7000 \mathrm{~m}$. Ima jedinstvenu konstrukciju sa krilima raspona 10 $\mathrm{m}$, dvojni potisni motor i repne površine $u$ obliku slova $V$. Korisni teret dostiže jednu trećinu poletne mase letelice, što govori o njenoj visokoj ae- rodinamičkoj efikasnosti. Moguća je upotreba izviđačko-osmatračke opreme, opreme za akviziciju i označavanje ciljeva, opreme za elektronsku i protivelektronsku borbu, kao i komunikacionih releja. HERMES-450 ima mogućnost potpuno autonomnog leta navigacijom pomoću sistema za globalno pozicioniranje. Radni komplet sistema čine letelica, upravljačka jedinica i link za prenos podataka.

HERMES-750 predstavlja poboljšanu varijantu BL HERMES-450, čiji su letni testovi započeti u januaru 1996. godine. HERMES-750 ima znatno veće gabarite, poletnu masu $750 \mathrm{~kg}$, znatno veći korisni teret i snažniji pogon. Predviđena izdržljivost je 30 časova pri letu na visini od $7600 \mathrm{~m}$.

$\mathrm{Na}$ pariskoj aero-izložbi firma "Silver Arrow« izložila je dva nova tipa BL: DARTER i COLIBRI.

DARTER je nadograđena i uvećana verzija BL MICRO VEE, projektovana prema američkim zahtevima za upotrebu na bliskim rastojanjima sa sledećim karakteristikama: akcioni radijus $92,6 \mathrm{~km}$, poletna masa $100 \mathrm{~kg}$, visina leta $6600 \mathrm{~m}$.

COLIBRI je vrlo jeftina $B L$, jednostavna i laka za održavanje, specijalno projektovana za obuku operatora koji ih navode.

Neke izraelske firme, kao što je EAS, razvijaju BL uglavnom za civilne potrebe. Tako je ova firma razvila četiri različita sistema BL namenjenih civilnim potrebama, ali koje se mogu koristiti i za vojne zadatke. To su: VANGUARD, CROW, FIREFLY i SNOOPER.

VANGUARD leti do visine od 5000 m sa poletnom masom $211 \mathrm{~kg}$, uključujući $40 \mathrm{~kg}$ korisnog tereta, uz izdržljivost od 16 časova. Ovaj model poleće sa poletne staze, dok ostala tri modela koriste raketne lansere. 
CROW leti do visine od $5000 \mathrm{~m}$ sa poletnom masom $70 \mathrm{~kg}$, uključujući $22 \mathrm{~kg}$ korisnog tereta uz izdržljivost od 9 časova.

FIREFLY leti do visine od 1520 $\mathrm{m}$, poletna masa mu je $21 \mathrm{~kg}$ uz izdržljivost od 4 časa.

SNOOPER leti do visine od 1000 $\mathrm{m}$, a poletna masa $\mathrm{mu}$ je $11 \mathrm{~kg}$ uz izdržljivost od 2 časa.

Glavne karakteristike BL firme EAS su: kompaktna konstrukcija, mala cena, dobra pokretljivost i rad sa posadom od dva do tri člana.

Izraelska firma "Emit" takođe, prema zahtevima tržišta, proizvodi $B L$ pod imenom STING 1 i STING 2.

STING 1 namenjen je za velike domete sa poletnom masom $1200 \mathrm{~kg}$ od čega 200 do $400 \mathrm{~kg}$ korisnog tereta i izdržljivošću od 35 do 48 časova.

STING 2 je laka i jeftina BL namenjena za bliska rastojanja sa poletnom masom od $100 \mathrm{~kg}$, korisnim teretom od 22 do $30 \mathrm{~kg}$ i izdržljivošću od 24 do 30 časova.

Pored navedenih programa Izrael je uključen i u razvoj nekih, za sada, futurističkih programa BL, kao što je program za presretanje raketa $u$ startnoj fazi (Boost Phased Interceptor). Ovaj program namenjen je za presretanje $i$ uništavanje raketa $u$ njihovoj startnoj fazi. Prema američkim izveštajima projekat je zamišljen kao sistem sa BL koja će leteti na velikoj visini, noseći antibalističku raketu. U okviru ovog projekta u toku su simulacione studije.

\section{Bespilotne letelice evropskih zemalja}

Programi razvoja BL evropskih zemalja nalaze se $u$ različitim fazama. $U$ nekim zemljama sistemi BL su uvedeni u operativnu upotrebu, druge zemlje ih razvijaju, treće su u fazi razvoj- nih studija, dok četvrte imaju neke već prilično tehnološki zastarele i prevaziđene sisteme. U pogledu podele, još uvek pod ruskim $i$ nemačkim uticajem, u najširoj upotrebi je podela na BL namenjene za izvršenje zadataka na taktičkom i operativnom nivou.

Taktički nivo podrazumeva upotrebu BL $\mathrm{u}$ armijskim jedinicama pukovima ili konsekventno povećanju disperzije jedinica, $u$ divizijama $\mathrm{i}$ njihovim jedinicama.

U Evropi se BL najčešće koriste za osmatračke zadatke sa TV, FLIR ili IC linijski skenirajućim elektro-optičkim senzorima, i za prikupljanje podataka o ciljevima za artiljerijske $\mathrm{i}$ raketne baterije. Ipak, zadatak prikupljanja podataka ponekad se može uspešno realizovati i laserskim meračem daljine. Sve vrste BL na ovom nivou izvedene su sa motornim pogonom, lansiraju se uz pomoć katapulta, a upravljane su daljinskim radio-komandama i(ili) preprogramiranim vođenjem sa sistemom inercijalne navigacije i ulaznim podacima sa sistema za globalno pozicioniranje (GPS). Po završetku zadatka BL uglavnom sleću uz pomoć padobrana.

Operativni nivo podrazumeva, uglavnom, unifikovane zadatke osmatranja sa elektro-optičkim senzorima $u$ armijskim jedinicama. Lansiranje se obavlja, uglavnom, uz pomoć katapulta, a prizemljenje pomoću padobrana. $\mathrm{Na}$ ovom nivou BL se, najčešće, pokreću uz pomoć turbo-mlaznih motora. Takvi sistemi su najrasprostranjeniji u zemljama bivšeg Varšavskog pakta, ali će, verovatno, u najskorije vreme biti zamenjeni drugim pogonima.

\section{Bespilotne letelice u evropskim zemljama}

\section{BELGIJA}

Od 1977. godine oružane snage Belgije koriste sistem EPEPVIER koji je proizvela firma "MBLE Defense» (sada 
"Thomson-CSF Electronics Belgium»). To je BL sa turbo-mlaznim pogonom koja ima malu izdržljivost (manje od 30 minuta), daljinsko upravljanje i preprogramirano vođenje. Upravljački elementi i sistem praćenja su na kraju svog veka, a zamena se očekuje u bliskoj budućnosti.

\section{BUGARSKA}

Od 1981. godine oružane snage $\mathrm{Bu}$ garske koriste sistem $\mathrm{BL}$ pod imenom JASTREB sopstvenog razvoja i proizvodnje. Najnovija verzija JASTREB-2MA proizvodi se od 1993. godine. Karakteriše ga preprogramirano vođenje. Bugarska je jedna od retkih zemalja čije BL za potrebe elektronske i protivelektronske borbe nose $i$ radio-ometače.

\section{ČESKA REPUBLIKA i MAĐARSKA}

Ceško RV trenutno koristi ruski sistem BL REJS/STRIŽ, ali od 1980. godine traži zamenu za sistem dugog dometa. Češki Vazduhoplovno-istraživački institut razvio je sistem $\mathrm{BL}$ pod $\mathrm{i}$ menom SOJKA i SOJKA III sa TV kamerama $i$ preprogramiranim $i$ poluautomatskim vođenjem. Od 1993. godine ovaj institut se udružio sa mađarskim Institutom za vojne tehnologije u proizvodnji BL SOJKA III za oružane snage obe zemlje. Serijska proizvodnja je počela 1995. godine.

\section{FRANCUSKA}

Francuske oružane snage koriste BL više nego ijedna druga evropska zemlja. Od 1989. godine na upotrebi se nalazi daljinski upravljana mini-izviđačka letelica pod imenom MART (Mini Avion de Reconnaissance Telepiloté) koja predstavlja dodatak artiljerijskom sistemu za upravljanje vatrom ATILA.
To je jedini evropski sistem koji je korišćen $u$ zalivskom ratu. Radi se, prvenstveno, o osmatračkom sistemu sa video linkom za daljine do $30 \mathrm{~km}$, koji može da nosi i opremu za elektronsku i protivelektronsku borbu. Francuske oružane snage imaju potrebu za znatno sofisticiranijim sistemom nego što je MART. Zbog toga je firma "SAGEM/ /SAT « razvila sistem BL CRECERELLE koji koristi britansku BL pod imenom SPECTRE. Elektro-optička oprema ovog sistema sadrži komplementarne TV i IC senzore sa širokim vidnim poljem i savremenim sistemom za obradu i interpretaciju slike. Ova BL ima prenosivu stanicu za daljinsko upravljanje, tako da jedinice s linije fronta mogu direktno da primaju sliku. Razvoj ovog sistema započeo je 1994. godine, a prvi sistemi su u operativnoj upotrebi od februara 1995. godine. Koristile su ga jedinice koje su bile raspoređene $u$ prethodnoj Jugoslaviji. CRECERELLE je isporučen $i$ oružanim snagama Holandije. Uvođenje ovog sistema $u$ operativnu upotrebu vezano je za kašnjenje realizacije francusko-nemačkog programa GIE BREVEL koje je dovelo do toga da su francuske oružane snage potražile sopstveno rešenje sa znatno sofisticiranijim zahtevima nego što su bili zahtevi za razvoj samog GIE BREVELA. Francuski BREVEL će biti u stanju da radi na dubini od $100 \mathrm{~km}$ iza prednje borbene linije sa izdržljivošću od preko 7 časova. Ova BL zasnovana je na prethodnoj eksperimentalnoj letelici TUCAN, firme »MBB«. Planira se da nosi FLIR kameru Carl Zeiss VBG $96 \times 4$, a "Matra Defense « ce proizvesti zemaljsku upravljačku stanicu. Predviđeno je da u operativnu upotrebu uđe 1999. godine.

Za duge domete ili izviđanje na operativnom nivou, francuske oružane snage koriste BL DASA/Canadair CL-289 pod imenom PIVER 289 (Programmation et Interpretation des Vols d'En- 
gins de Reconnaissance). Od 1992. godine proizvedena su 3 lansirna sistema i 55 letelica ove vrste. Proizvodnja je završena 1993. godine, a do 2000 . godine planira se uvođenje novih BL.

Francuske jedinice $u$ sastavu UNPROFOR-a u Bosni, između oktobra 1993. godine i februara 1994. godine, koristile su svoje BL malog dometa tipa FOX AT. Ovaj sistem razvila je firma "CAC Systemes" sa izdržljivošću od oko 5 časova i masom ograničenom na $25 \mathrm{~kg}$. AT verzija je jedna od tri moguće. Na upotrebi u toku zime 1993/94. u Bosni u bihaćkom džepu na upotrebi je bila varijanta AT1 sa radio-upravljanjem, dok verzija AT2 nudi mogućnost preprogramiranja. Verzija TX namenjena za elektronsku i protivelektronsku borbu, uvedena je $u$ operativnu upotrebu 1995. godine. Verzija TS je namenjena za akviziciju podataka o cilju.

\section{NEMAČKA}

Nemačke oružane snage za sada koriste samo francusku BL tipa CL-289 .

Izvesno je da će se na taktičkom nivou, po završetku zajedničkog razvoja s Francuskom, koristiti BL BREVEL.

U pogledu zahteva nemačkih oružanih snaga za nabavkom BL dugog dometa, verovatno će letelica TUCAN biti osnova za razvoj nemačkih BL pod imenom TAIFUN i MUCKE. BL TAIFUN je namenjena za zadatke protivoklopne borbe, tj. za artiljeriju i njene komandne centre. Vođenje će biti realizovano uz pomoć autopilota za praćenje terena TERCOM, (terrain contour-matching) $\mathrm{i}$ radarskim senzorom u milimetarskom području. BL MUC$\mathrm{KE}$ je namenjena za ometanje telekomunikacija. Razvoj ovih sistema započeo je 1996. godine.

\section{GRČKA}

Grčka je 1990. godine započela sa razvojem svoje BL PEGASUS, ali nije poznato u kojoj fazi se ovaj program nalazi.

\section{ITALIJA}

Kao sastavni deo svog $\mathrm{C}^{3} \mathrm{I}$ sistema CATRIN (Sistema CAmpale di TRasmissione ed INformazioni), italijanske oružane snage imaju podsistem SORAO (Sottosistema di SORveglianza ed Acquisizione Obiettivi) za osmatranje i akviziciju podataka o cilju. Radi opitovanja i operativnog ocenjivanja sistem je prvo bio instaliran na BL METEOR MIRACH 20, a sada je na BL MIRACH 26. Ovaj sistem je namenjen za izvršavanje zadataka na taktičkom nivou.

Za upotrebu na operativnom nivou, sistem SORAO je ugrađen na BL MIRACH 150 . Za te potrebe dodati su elektro-optički senzori, specijalni radari ili oprema za elektronsku i protivelektronsku borbu. Jedan ovako koncipiran sistem nalazi se u procesu opitovanja i ocenjivanja od 1993. godine.

Radi obezbeđivanja sistema BL za kratke domete, jedna BL se trenutno nalazi na ocenjivanju letnih karakteristika.

\section{HOLANDIJA}

Holandija je nabavila izviđački sistem BL za upotrebu na taktičkom nivou. U užem izboru su se našla tri sistema: CRECERELLE, RANGER i BREVEL, a izabran je francuski sistem BL CRECERELLE.

\section{RUSIJA}

Prvi sistemi BL $u$ bivšoj sovjetskoj armiji bili su TBR-1, uvedeni u operativnu upotrebu pre 20 godina. 
Bivša sovjetska armija razvila je zatim STERK sa BL SMELJ-1. U upotrebi se nalazi oko 50 ovih sistema. Sistem je specifičan po tome što je montiran na šasiju prikolice BMD koja služi kao transporter, lanser i upravljačka stanica. Sa ove stanice može se direknto upravljati sa BL do udaljenosti od $60 \mathrm{~km} \mathrm{u}$ slučajevima gde se ne zahteva preprogramirani let BL.

Od 1993. godine kao zamena ovom sistemu započeo je razvoj novog sistema COLIBRI koji je zbog nedostatka novčanih sredstava obustavljen. Za neznatno veće udaljenosti, Rusija poseduje i sistem STRIŽ, čija se BL lansira sa zemlje, tj. sa vozila BAZ 135 SPU $8 \times 8$ koje istovremeno predstavlja transporter i lanser. Senzori ugrađeni u ovaj sistem su optička kamera PA-1 ili elektrooptička ČIBIS-B sa koje se video signal šalje na zemlju preko linka.

Pored Rusije sisteme REJS/STRIŽ poseduju i Čška, Slovačka, Mađarska, Ukrajina i Belorusija.

\section{ŠPANIJA}

Od 1993. godine u saradnji sa firmom »Dornier« španski nacionalni institut za aviotehniku INTA (Instituto de Tecnika Aeroespacia) razvija BL SIVA (Sistema Integrado de Vigilancia Aerea) koja predstavlja integrisani osmatrački sistem. Sistem je montiran na teretno vozilo, a u sastav kompleta ulaze 4 letelice koje imaju mogućnost osmatranja, akvizicije podataka o cilju ili izviđanja. Izdržljivost BL je 8 časova. Specifičnost vezana za ovu BL je posedovanje pomoćnih rezervoara za gorivo smeštenih ispod krila koji omogućavaju 2 dodatna časa leta.

\section{ŠVEDSKA}

Od pre nekoliko godina Švedska je definisala zahteve za svoj taktički sistem $\mathrm{BL}$ sa akcionim radijusom od $\mathbf{5 0}$ $\mathrm{km}$. Od 1994. godine sistem sa jedinstvenom BL s autonomnim žiroskopom pod imenom MIDGET nalazi se na opitovanju i ocenjivanju. Zvanična švedska klasifikacija ovog sistema je TecMentRPG (Technology Management Remotely Piloted Gyroplane).

\section{ŠVAJCARSKA}

Švajcarska razvija svoju BL pod imenom RANGER po izraelskom projektu i sa izraelskim senzorima. Takođe, letelica je zasnovana na izraelskoj BL SCOUT, ali je prilagođena za uslove specifičnog reljefa $i$ prirodne sredine Švajcarske. Specifičnost vezana za ovaj sistem je mogućnost prizemljenja pomoću padobrana i točkova. Sistem je bio na opitovanju i ocenjivanju od 1990. godine, a u operativnu upotrebu je uveden 1995. godine. RANGER je namenjen za upotrebu u dnevnim i noćnim uslovima. Radi u realnom vremenu na daljinama od 100 $\mathrm{km}$, visini od $500 \mathrm{~m}$, a izdržljivost $\mathrm{mu}$ je 5 časova.

\section{TURSKA}

Zahtevi turskih oružanih snaga za osmatranjem i prikupljanjem podataka o cilju na taktičkom nivou definisani su pre nekoliko godina. Za sada je $u$ toku opitovanje i ocenjivanje dva američka sistema dugog dometa.

Prvi sistem je SHADOW 600 sa višenamenskom BL koja može da nosi FLIR i TV kamere i opremu za elektronsku i protivelektronsku borbu. $\mathrm{O}$ va $B L$ poleće $i$ sleće na točkove i ima izdržljivost od 14 časova leta.

Drugi sistem je već opisani GNAT 750 firme »General Atomics« koji se nalazi na opitovanju i ocenjivanju od 1993. godine. Pored ovih uvoznih BL Turska, u firmi TAI ( Tusas Aerospace Industries«), razvija sopstveni sistem pod imenom UAV-1X koji se od proš- 


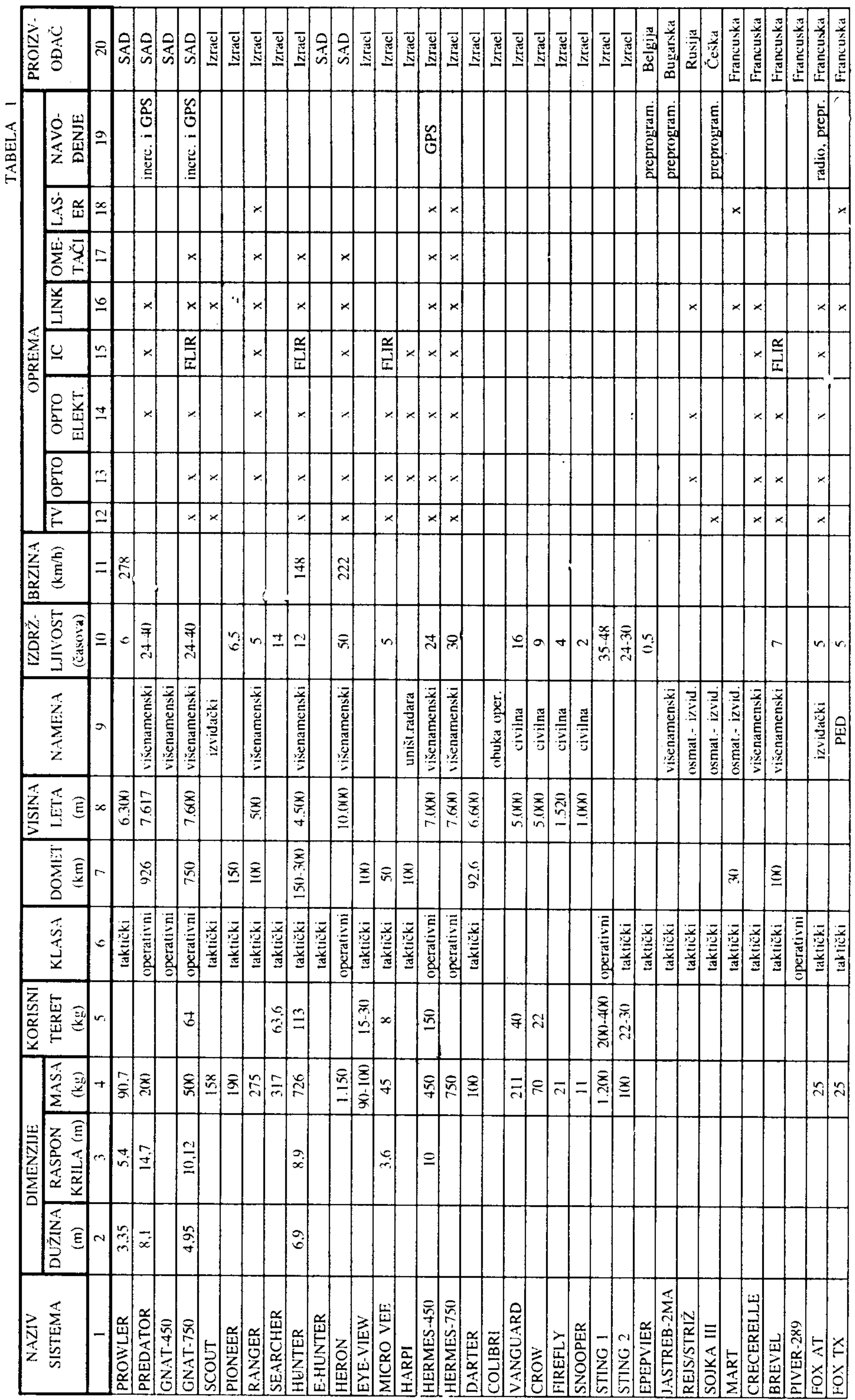




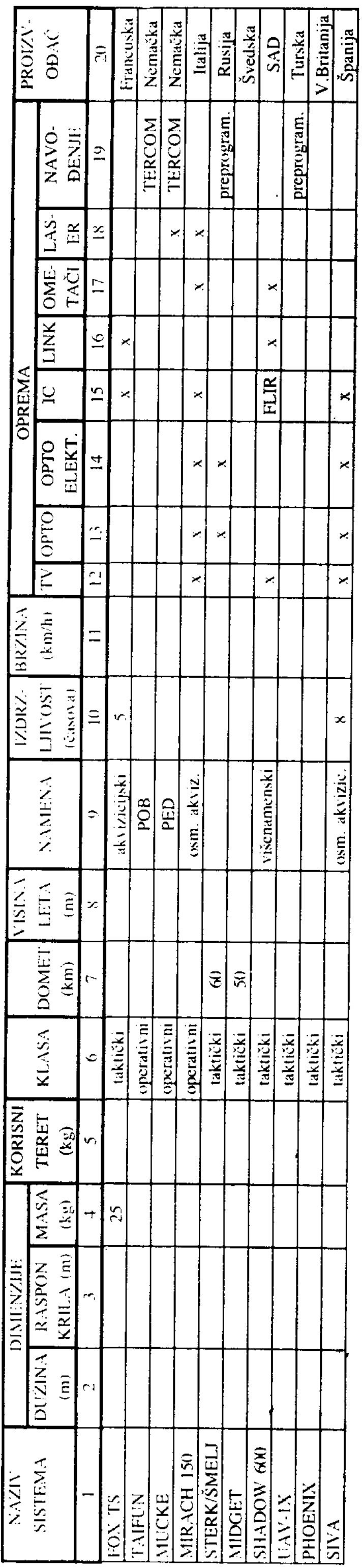


le godine nalazi na opitovanju i ocenjivanju. Ova letelica ima preprogramirano vođenje sa senzorima čiji izbor može biti opcioni u zavisnosti od namene, tj. prirode zadatka koji se postavlja pred BL.

Pregled tipova BL i njihovih karakteristika, prema dostupnim informacijama, prikazan je u tabeli 1 .

\section{Zaključak}

Bespilotne letelice predstavljaju još jedan korak u »tehnologizaciji« rata i integraciji ratišta za koje je karakteristično sve manje učešće čoveka u izvršavanju zadataka koji ga mogu dovesti u neposrednu opasnost. Da bi se stekla prednost $u$ odnosu na neprijatelja, potrebno je prikupiti što vi- še podataka o njemu, i u realnom vremenu ih proslediti komandnim centrima, kako bi se realizovao koncept borbe $s$ distance i na taj način maksimalno zaštitio sopstveni vojnik na čiji su gubitak javnosti svih zapadnih zemalja vrlo osetljive. Uprkos izvesnim budžetskim ograničenjima, razvoj BL se intenzivira, tim pre što $u$ njemu učestvuju i specijalizovane obaveštajne agencije, kao što je CIA sa novčanim sredstvima iz svojih budžeta. Ipak, radi smanjenja ukupnih troškova, najnoviji trendovi usmereni su na razvoj univerzalnih $\mathrm{BL}$ sa zamenljivom opremom i senzorima koji se kompletiraju $\mathrm{u}$ zavisnosti od postavljenog zadatka. U pogledu aerodinamičke konstrukcije ide se ka konfiguracijama sa što boljim aerodinamičkim iskorišćenjem kod kojih je već danas ostvaren odnos mase korisnog tereta $\mathrm{i}$ poletne mase $1: 3$.

Literatura:

[1] Military technology, 1995, 1996.

[2] International Defence Review, 1995, 1996.

[3] Terre magazine, 1996. 